with suggestions or disagreements. Any comments or suggestions can be made to your divisional representative or the officers of the CTC through the College.

The Committee would also welcome greater competition in the elections to the CTC. It is quite often the case that not enough trainees stand for an election to be necessary. Elections are held every two years in each division; Inceptors are as eligible as members.

Peter White

Chairman

Collegiate Trainees' Committee
REFERENCES

${ }^{1}$ Department of Health and Social Security, Joint Consultants Committee, Chairmen of regional health authorities (1986) Hospital medical staffing: achieving a balance. London: DHSS.

${ }^{2}$ British Medical Journal (1987) Manpower package 'welcomed' by 80 votes to 75. British Medical Journal, 294, 66-68.

${ }^{3}$ KINGDON, D. G. \& SzULECKA, T. K. (1986) Establishing a distinct psychiatric service without psychiatric trainees. Bulletin of The Royal College of Psychiatrists, 10, 338-340.

'TURNER, T. H. (1986) Whatever happened to stigma? Bulletin of the Royal College of Psychiatrists, 10, 8-9.

${ }^{5}$ Morrison, A. (1985)-Psychiatry in decline-A personal view. Bulletin of The Royal College of Psychiatrist, 9, 4-7.

\title{
Notes of Guidance for Representatives on Advisory (Consultant) Appointments Committees
}

The Notes of Guidance, published in the Bulletin (August $1986,10,200-201$ ) drew the attention of College representatives to questions of racial and sexual discrimination and health as follows:

Employers in the United Kingdom and Eire are required by law not to discriminate on grounds of race or of sex against their employees or their candidates for employment. The College representative is expected to insist that this principle is at all time scrupulously observed during the proceedings of the Committee.

Service on an Advisory Appointments Committee may possibly result in its members having to appear before a Tribunal in a race or sex discrimination case. It would be prudent for members to make and keep in their own possession notes about the candidates and the proceedings of the Committee if such an appeal seems at all likely. If a representative is in any way concerned that there has been an irregularity in the proceedings of the Appointment Committee he should notify the President of the College.

It is not the task of the Appointments Committee to make a judgment on the physical or mental health of a candidate. If, however, serious doubt regarding health does arise during the course of an interview, the College Assessor should apply the usual criteria of suitability and may wish to make a recommendation for appointment subject to satisfactory medical examination.

The Court of Electors recently affirmed that this guidance should apply not only to Consultant appointments but also both to Senior Registrar appointments (where the College representative-usually the Regional Adviser or his/her nominee-would be present) and to the appointment of all other grades of medical staff, when Members of the College should ensure that the Guidelines are scrupulously observed.

\section{Special Committee on Unethical Psychiatric Practices}

At the recommendation of the Special Committee on the Political Abuse of Psychiatry, Council has agreed to revise the remit of that body and it will now be empowered to deal with all aspects of unethical psychiatric practices, throughout the world, when it is clear that the College should, as a matter of principle, voice its concern.

In accordance with this recommendation, the title of the Special Committee has now been changed to Special Committee on Unethical Psychiatric Practices.

Council endorsed Professor Ken Rawnsley as the new Chairman of the Special Committee and expressed its appreciation of the work undertaken by Dr Peter Sainsbury, both in public and behind the scenes, during the eight years he was Chairman of the Special Committee on the Political Abuse of Psychiatry.

\section{Repeat of Christmas Lecture}

Due to the success of the College's first Christmas Lecture for Young People, Professor Anthony Clare has agreed to give a repeat of this lecture entitled 'Aren't We All a Little Mad?' on Friday, 3 April 1987 at 3.00 p.m. at the Royal
Society, 6 Carlton House Terrace, London SW1. Applications for tickets must be made in advance and are available from Deborah Hart, Royal College of Psychiatrists, 17 Belgrave Square, London SWIX 8PG. 